\title{
The importance of long time-series in understanding the variability of natural systems
}

\author{
A. J. Southward \\ Marine Biological Association; Citadel Hill, Plymouth PL1 2PB, United Kingdom
}

\begin{abstract}
The Marine Biological Association possesses long time-series of data on the biota and environment of the western English Channel. These series are of value in tracing the influence of climate change on marine communities and show the importance of continuity and length for detection of cycles and prediction of future changes.
\end{abstract}

\section{INTRODUCTION}

Marine organisms can have life times that range from hours to decades. Many of the familiar seashore invertebrates and inshore fish fall into the upper limit of this scale, with life-spans of 10 to 20 years. A much wider time span is shown by climate fluctuations which can occur on scales from less than $12 \mathrm{~h}$ to 100000 years or more. Thus, to determine the natural variability of marine ecosystems, we need to encompass a monitoring period that corresponds to the expected lifetime of the dominant organisms and the time scale of the most important environmental factor that influences them. Above all, monitoring needs to be continued from year to year so that natural cycles of varying frequency can be extracted and a predictive capacity can be developed.

\section{THE PLYMOUTH TIME SERIES}

The biota and the environmental factors of the western English Channel were monitored by the Marine Biological Association from soon after the opening of the Plymouth Laboratory in 1888 until 1988. Table 1 lists the series of investigations available. At first, monitoring was carried out in a qualitative or semi-quantitative manner, recording occurrences and non-occurrences of "exotic" species, sometimes with an estimate of relative abundance. An example can be taken from the early data on the occurrence of the siphonophore Muggiaea (Bles, 1892; Browne, 1895; Garstang, 1895; Hodgson, 1895). The influx of large numbers of this species in the autumn months of the 1890 's led to speculation about its origin from the warmer waters to the south west of the entrance to the Channel and the implications of the presumed flow of water to the fisheries. A tug was chartered for quarterly sampling from Plymouth across to Ushant and beyond in 1899-1890 (Lankester et al., 1899), and quantitative methods were introduced by Walter Garstang, who was influenced by the ideas of Viktor Hensen and the German school of plankton investigators. Acquisition of ocean-going vessels in 1901 and 1902 allowed greater continuity of monitoring. The published series on plankton and hydro- 
Table 1. The Marine Biological Association's time series for the Plymouth area and the western English Channel off Plymouth

\begin{tabular}{|ll|}
\hline \multicolumn{1}{|c|}{ Parameter } & \multicolumn{1}{c|}{ Year } \\
\hline Sea temperature and salinity & $1902-1987$ \\
Inorganic nutrients & $1921-1987$ \\
Dissolved organic nutrients & $1964-1987$ \\
Net phytoplankton & $1903-1988$ \\
Zooplankton & $1903-1988$ \\
Planktonic stages of fish & $1924-1988$ \\
Demersal fish & $1913,1920^{\circ}$, 1950's, 1970's $^{\prime}$ \\
Intertidal barnacles & $1950-1992$ \\
\hline
\end{tabular}

graphy, from 1902 to 1907, covered the entire English Channel four times a year (Gough, 1905, 1907; Bygrave, 1911). The sampling involved quantitative vertical nets and horizontal tows at several depths with closing nets, but only part of the results were published. The hydrographic work included not only water bottle casts at fixed stations by research vessels, but also a series of surface temperatures and salinity samples taken from "ships of opportunity" on regular commercial lines (Matthews, 1905, 1909, 1911). This first continuous Plymouth series ceased when government funding was withdrawn in 1910 .

A new monthly series on hydrography and water chemistry was begun in 1921 by W. R. G. Atkins \& H. W. Harvey (Atkins, 1926; Harvey, 1925) who devised improved techniques for analysis of phytoplankton nutrients. A weekly zooplankton series using large nets towed on oblique paths was begun in 1924 by F. S. Russell who developed the concept of "plankton indicator species" to demonstrate hydrographic changes not then detectable by physical methods (Russell, 1933, 1935, 1936, 1937). Russell included the pelagic stages of fish in his enumeration, showing how their seasonal abundance was linked to environmental factors (Russell, 1973). Studies of the indicator concept and fluctuations in young fish were continued and extended to the Celtic Sea and western approaches by Corbin (1947) and Southward (1962, 1970, 1984). Most of the cruises from 1921 to 1939 were confined to the western end of the Channel, and nearly all the zooplankton samples were taken off Plymouth. After 1953, with acquisition of newer vessels, sampling was extended across the Channel and out into the Celtic Sea at monthly or bimonthly intervals (Armstrong \& Butler, 1962; Armstrong et al., 1974) following the lines of stations laid down during the investigations in 1899-1907. After 1975, activites were more restricted to the Western Channel and off Plymouth, but increased emphasis was given to dissolved organic components of the production cycle (Butler et al., 1979) and to phytoplankton (Boalch, 1987).

The zooplankton time series off Plymouth continued until 1988, when government funding was withdrawn again (Southward, 1980, 1984; Southward \& Boalch, 1988). Allied investigations on phytoplankton, fish and benthic invertebrates were made on $a$ less continuous basis, but the changes in algal abundance and distribution, in benthic populations and in species composition of the trawl catches could be tied into the zooplankton series (Boalch et al., 1978; Maddock et al, 1981, 1989; Holme, 1983; 
Southward, 1983; Boalch, 1987). A series on intertidal animals has been continued from 1950 to date (Southward, 1967, 1991) and can be taken back to baseline surveys in the 1930's (Moore, 1936; Fischer-Piette, 1937).

The Plymouth series illustrate the value of long-term and sustained monitoring. The work by Russell in 1924-1939 coincided with a period of rising temperatures in the northern hemisphere, when there were massive changes in plankton and fish in the Channel (Russell, 1933, 1937). The effect was detected first among the biota and in nutrient chemistry. It was shown much later, after rigorous analysis of the records, that there had been a physical change and that the average annual temperature had risen in the English Channel as well as in the Arctic (Cooper, 1958; Southward, 1960, 1963; Maddock \& Swan, 1977).

In the earlier investigations of the biological change, which included the loss of a substantial herring fishery, variability tended to be ascribed to alterations in the nutrient levels and primary production ("new production") as a result of changes in water movements. In later years it became apparent that the variability in dissolved nutrients was only one of many factors that could be linked to change in climate (Southward, 1963; Russell et al., 1971; Russell, 1973; Cushing \& Dickson, 1976; Cushing, 1982). This conclusion was strengthened after 1960, when many of the changes seen in the 1930's were reversed during a period of cooling climate (Southward et al., 1975; Southward, 1980). More recent warming since 1980 has produced another phase of the cycle (Southward \& Boalch, 1988; Southward et al., 1988). Within this broad climate-induced cycle, which is linked to global change, there are shorter term cycles. A number of organisms show a correlation with the quasidecadal solar (sunspot) cycle and its 22-year harmonic, but this link is most obvious during periods of sustained longer cycle warming (Southward et al., 1975; Southward, 1980; Southward et al., 1988).

\section{CONCLUSIONS}

If major changes in biota can occur in cycles of 11 to 45 years or more, as the English Channel series show, then monitoring must be sustained for very long periods indeed to extract major trends and permit forecasting. It is not possible to do any sustained ecosystem research, even low budget studies of the intertidal zone, on the basis of shortterm contracts of the order of 3-5 years duration, which is all that is available from U.K. government sources at present.

Acknowledgements. Thanks are due to all those who worked at Plymouth in the past, for their devotion in continuing this important series of observations.

\section{LITERATURE CITED}

Atkins, W. R. G., 1926. A quantitative consideration of some factors concerned with plant growth in water. - J. Cons. perm. int. Explor. Mer 1, 197-226.

Armstrong, F. A. J. \& Butler, E. I., 1962. Hydrographic surveys off Plymouth in 1959 and 1960. J. mar. biol, Ass, U.K. 42, 445-463.

Armstrong, F. A. J., Butler, E. I. \& Boalch, G. T., 1974. Hydrographic and nutrient chemistry surveys in the western English Channel during 1965 and 1966. - J mar biol. Ass. U.K 54, 895-914. 
Bles, E. J., 1892. Notes on the plankton observed at Plymouth during June, July, August, and September, 1892. - J. mar. biol. Ass. U.K. 2, 340-343.

Boalch, G. T., 1987. Changes in the phytoplankton of the western English Channel in recent years. Br. phycol. J. 22, 226-235.

Boalch, G. T., Harbour, D. S. \& Butler, E. I., 1978. Seasonal phytoplankton production in the western English Channel 1964-1974. - J. mar. biol. Ass. U.K. 58, 943-953.

Browne, E. T., 1895. On the changes in the pelagic fauna of Plymouth during September 1893 and 1895. - J. mar. biol. Ass. U.K. 4, 168-173.

Butler, E. I., Knox, S. \& Liddicoat, M. L., 1979. The relationship between inorganic and organic nutrients in sea water. - J. mar. biol. Ass. U.K. 59, 239-250.

Bygrave, W., 1911. Report on the plankton of the English Channel in 1906. - Rep. N. Sea Fish. Invest. Commn (Southern Area) 1906-1908, 235-268.

Cooper, L. H. N., 1958. Sea temperatures in Plymouth Sound. - J. mar. biol. Ass. U.K. 37, 1-3.

Corbin, P. G., 1947. The spawning of mackerel, Scomber scombrus L., and pilchard, Clupea pilchardus Walbaum, in the Celtic Sea in 1937-1939, with observations on the zooplankton indicator species, Sagitta and Muggiaea, - J. mar. biol. Ass. U.K. 27, 65-132.

Cushing, D. H., 1982. Climate and fisheries. Acad. Press, London, $373 \mathrm{pp}$.

Cushing, D. H. \& Dickson, R. R., 1976. The biological response in the sea to climatic change. - Adv. mar. Biol. 14, 1-122.

Fischer-Piette, E., 1937. Etudes sur la biogéographie intercôtidale des deux rives de la Manche. J. Linn. Soc. (Zool.) 60, 181-272.

Garstang, W., 1895. Faunistic notes at Plymouth during 1893-1894. - J. mar. biol. Ass. U.K. 3, 210-235.

Gough, L. H., 1905. Report on the plankton of the English Channel in 1903. - Rep. N. Sea Fish. Invest. Commn (Southern Area) 1902-1903, 325-377.

Gough, L. H., 1907. Report on the plankton of the English Channel in 1904 and 1905. - Rep. N. Sea Fish. Invest. Commn (Southern Area) 1904-1905 (1), 165-268.

Harvey, H. W., 1925. Water movement and sea temperature in the English Channel. - J. mar. biol. Ass. U.K. 13, 569-664.

Hodgson, T. V., 1895. Notes on the pelagic fauna at Plymouth, August-December, 1895. - J. mar. biol. Ass. U.K. 4, 173-178.

Holme, N. A., 1983. Fluctuations in the benthos of the western English Channel. In: Fluctuation et succession dans les écosystèmes marins. Actes du $17^{\mathrm{e}}$ Symposium Européen de Biologie Marine. Gauthier-Villars, Paris, 121-124. (Océanol. Acta Vol. spéc.)

Lankester, E. R., Herdman, W. A., Dickson, H. N. \& Garstang, W., 1899. Report of the committee appointed to make periodic investigations of the plankton and physical conditions of the English Channel during 1899. - Rep. Br. Ass. Advmt Sci. 1899, 444-446.

Maddock, L. \& Swann, C. L., 1977. A statistical analysis of some trends in sea temperature and climate in the Plymouth area in the last 70 years, - J. mar. biol. Ass. U.K. 57, 317-338.

Maddock, L., Boalch, G. T. \& Harbour, D. S., 1981. Populations of phytoplankton in the western English Channel between 1964 and 1974. - J. mar. biol. Ass. U.K. 61, 565-583.

Maddock, L., Harbour, D. S. \& Boalch, G. T., 1989. Seasonal and year-to-year changes in the phytoplankton from the Plymouth area, 1963-1986. - J. mar. biol. Ass. U.K. 69, 229-244.

Matthews, D. J., 1905. Report on the physical conditions in the English Channel, 1902-1903. - Rep: N. Sea Fish. Invest. Commn (Southern Area) 1902-1903, 289-324.

Matthews, D. J., 1909. Report on the physical conditions in the English Channel and adjacent waters, 1904 and 1905. - Rep. N. Sea Fish. Invest. Commn (Southern Area) 1904-1905 (2), 281-345.

Matthews, D. J., 1911. Report on the physical conditions in the English Channel and adjacent waters, 1906. - Rep. N. Sea Fish. Invest. Commn (Southern Area) 1906-1908, 269-282.

Moore, H. B., 1936. The biology of Balanus balanoides. V. Distribution in the Plymouth area. - J. mar. biol. Ass. U.K. 20, 701-716.

Russell, F. S., 1933. The seasonal distribution of macroplankton as shown by catches in the 2-metre stramin ring trawl in offshore waters of Plymouth. - J. mar. biol. Ass. U.K. 19, 73-82.

Russell, F. S., 1935. On the value of certain plankton animals as indicators of water movements in the English Channel and North Sea. - J, mar. biol Ass. U.K. 20, 309-322.

Russell, F.S., 1936. Observations on the distribution of plankton animal indicators made on Col. E. T. 
Peel's yacht "St. George" in the mouth of the English Channel, July, 1935. - J. mar. biol. Ass. U.K. 20,507-522.

Russell, F. S., 1937. The seasonal occurrence of the pelagic young of teleostean fishes in the Plymouth area. Pt. IV.: The year 1936, with notes on the conditions as shown by the occurrence of plankton indicators. - J. mar. biol. Ass. U.K. 21,679-686.

Russell, F. S., 1973. A summary of the observations on the occurrence of the planktonic stages of fish off Plymouth 1924-1972. - J. mar. biol. Ass. U.K. 53, 347-355

Russell, F. S., Southward, A. J., Boalch, G. T. \& Butler, E. I., 1971. Changes in biological conditions in the English Channel off Plymouth during the last half-century. - Nature, Lond. 234, 468-470.

Southward, A. J., 1960. On changes of sea temperature in the English Channel. - J. mar. biol. Ass. U.K. $39,449-448$.

Southward, A. J., 1962. The distribution of some plankton animals in the English Channel and approaches. II.: Surveys with the Gulf III high-speed sampler, 1958-1960. - J. mar. biol. Ass. U.K. $42,275-375$.

Southward, A. J., 1963. The distribution of some plankton animals in the English Channel and approaches. III.: Theories about long term biological changes, including fish. - J. mar. biol. Ass. U.K. 43, 1-29.

Southward, A. J., 1967. Recent changes in abundance of intertidal barnacles in south-west England, a possible effect of climatic deterioration. - J. mar. biol. Ass. U.K. 47, 81-95.

Southward, A. J., 1970. Improved methods of sampling post-larval young fish and macroplankton. J. mar. biol. Ass. U.K. 50,689-712.

Southward, A. J., 1980. The western English Channel - an inconstant ecosystem? - Nature, Lond. $285,361-366$.

Southward, A. J., 1983. Fluctuations in the ecosystem of the western Channel, a summary of studies in progress. In: Fluctuation et succession dans les écosystèmes marins. Actes du $17^{\mathrm{e}}$ Symposium Européen de Biologie Marine. Gauthier-Villars, Paris, 187-189. (Océanol. Acta Vol. spéc.)

Southward, A. J., 1984. Fluctuations in the "indicator" chaetognaths Sagitta elegans and Sagitta setosa in the western Channel. - Oceanol. Acta 7, 229-239.

Southward, A. J., 1991. Forty years of changes in species composition and population density of barnacles on a rocky shore near Plymouth. - J. mar. biol. Ass. U.K. 71, 495-513.

Southward, A. J. \& Boalch, G. T., 1988. Aspects of long-term changes in the ecosystem of the western English Channel in relation to fish populations. In: Long term changes in fish populations. Ed. by T. Wyatt \& M. G. Larraneta. Instituto de Investigaciones Marinas de Vigo, Vigo, 415-447.

Southward, A. J., Butler, E. I. \& Pennycuick, L., 1975. Recent cyclic changes in climate and in abundance of marine life. - Nature, Lond. 253, 714-717.

Southward, A. J., Boalch, G. T. \& Maddock, L., 1988. Fluctuations in the herring and pilchard fisheries of Devon and Cornwall linked to change in climate since the 16 th century. - J. mar. biol. Ass. U.K. $68,423-445$. 